\title{
The Taxation of Pope Nicholas IV
}

THE taration of Pope Nicholas IV is recognised as a very 1 important record, because until 1585 the grants of the clergy in parliament and convocation were bared upon it, lands acquired after 1291 being texed with those of the laity.' The assesement is distingaished from the Norrich taration as a torus valor," and in recent years it has been frequently assumed thet a verus ralor represented the income of religious honses and ecclesiastical benefices in 1891, but the question whether that income was net or grose is left open. An attempt is made in this peper to discover the meaning of the rerus valor by investigating the relation of the taration of Pope Nicholas to ecclesiastical revenues, and to other agsesments of the thirtenth century.

'Three assessments have been made in turn for the oppression of holy church; the first is called that of Walter, bishop of Nortich, the second is of Master Raymond de Nogeriis, the third of Bishops John of Winchester and Oliver of Lincoln.' ${ }^{2}$ To this statement in his Liber Demorandorum the cenon of Barnwell added an epigramatic comment: Prima tollerabilis, secunda graxis, tercia graviesima. Prima pungit, secunda vulnerat, tercia usque ad assa excoriat. The origin of all of them was a papal grant of tenths for the Holy Land. On the pretert of a crusade Henry WI obtained from Innocent IV a grant of the tenths of the revenues of the

1 Btubbe, Constitutional Butory, od. 18997, it. 580.

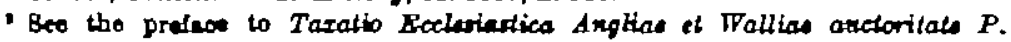
Nichalai $I V$, pablished by the Record Commiestoo, 1808 (hencelorth reforred to an

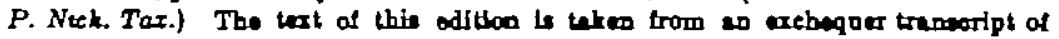
the Aftenth antury, and is ald to here bees oolletod with a number of oridnal rolle (thow ere calendered in Apoonnte of Chorkeal Babeidien [Nise. Exehequer

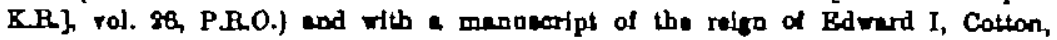
Tibertus C. x, whiob wa demared in the fre of 17:1. Howerer in the Cotion N8.

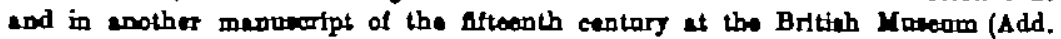
24060) the appropriation of eboreben in the archdeneonry of Hiddleses are noted, whereas they do not eppear in the printed text In bis edftbos $\alpha$ a text for the dioom of Exeter trom a manecript of the thirtoenth ar arby fourtennth centary in the Bishop of Eroter' Regitiry Nr. F. C. Hingraton.Rendoiph (Rigisters of Browe. cambs. Quivil, Byttoth and the Taxotron of Popo Necholas, p. 160) wetes thet the text of the Record Commenton is 'fall of unecourncia.'

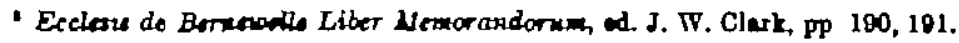


churah for three years, and on 18 October 1852, at an assambly of the biahope in London, he produced the pepal mandate authorifing him to levy the tenth not on the encient assessment of churches, bat on a new and stringent valuation according to the will and decision of his servants and tar-gatherers." The opposition of Groseteste and other bishope foiled the king for a time. In 1253 Henry III informed Innocent IV that he would set out for the Holy Land on the fenst of the Nativity of Bt. John the Beptist 1256," and on 11 Beptember 1253 Innocent IV sent a mandate to the biahope of Norwich and Chichester and the abbot of Westminster to act as collectors." At a great council held at Westmingter on 86 April 1254 the king's request for the papal tenth for three years was granted,' and on 4 July the collectors pablished their mandate." Mennmile on $24 \mathrm{May}$ Innocent IV extended the period of the grant to fivo years, allowing the king to use the money for the advancement of his eon Edmand's claims to the throne of Sicily."

The asesment which was made in the course of the year was known as the Norwich taxation, beceuse Walter Suffield, bishop of Norwich, was mainly responsible for it. He sont letters in his own name to the rural deans of every diocese throughout the realn, and in every ruridecanal chapter the dean and three or four rectors of authority took an oath to assess the benefices according to a iusto cotumatio. They were bidden to ascertain the truth either of their own knowledge or that of the member of the chapter, and they had power to compel any pereons in their deanaries to make statements on oath. ${ }^{10}$ The bishop rarned them to exercise great care in making a true assessment, without regard to any previous aseassments. They had also to asess any property in the rural deanery belonging to religious houses and cells ontside it, and all tithes held in severnalty by religious houses. Suffield moreover sent lettars to the religions house demanding a iusta estimatio of all their immovable property, i.e. their lands and tenements, with the exception of lands in other rural deaneries, or those which were beld by barong or fell to the crown during a vacancy. ${ }^{11}$ This return was made by aworn men of the chapters of cathedrals and monasteries. The bishop of Norwich was at 8t. Albans on 11 Jaly making the sasessment in person; ${ }^{1 s}$ he summoned the obedientiars of the monsstery before him, including the almoners, to assess the property of their offices. The heads of the two leper hospitals and of the poor

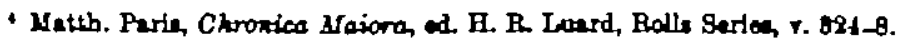

- Hymer, Foedra (Record Comminion), 1288.

- Hetth. Pera, N. 20.

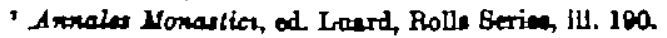

- Nattb. Perles N. 207.

- Ibid. v. 458 ; Rymor, Fondera, L 200.

- A wivala Monation, i. 328.

n Natth. Paris, T. 181.

11 Toid p 328 . 
nunnery of Sopwell and the rectors and vicars of the exempt jurisdiction of St. Albans were compelled to assess their benefices. The bishop protested that he acted under compulsion, as the monk of Barton also bore witneas, and Matthew Paris, while assailing this tenth in unmeasured terms as ' on innovation unheerd of through the centuries,' admitted that the bishop diacharged his office rith the utmost moderation and faithfulness. The assessment made by the rural deans of the four archdeaconries of the diocese of Norwich has fortanetely been preserved in the Liber Albus of Bury St. Edmunds, ${ }^{13}$ and is now being edited by the Rer. William Hudson for the Norwich Archæological Society. The Norwich taration of the spiritualities of the diocese of Ely was included by the canon of Barnwell in his Liber Menolandorum." The essessment of the spiritualities and temporalities of Malmesbury $\Delta b$ bey is entered in the register of the house," that of part of the temporalitie of Bury 8t. Edmunds is in one manuscript of the chronicle of John of Everisden, "and a summary of the essessments of all the houses of the order of Bempringham is in the cartulary of Malton Priory. ${ }^{17}$

The bishop of Norwich's avowed antrillingneas may have filled Henry III rith distrust, for he gave instructions for an independent inquiry. On 9 Oetober 1254 he sent a mandate from Bordeaux to Hugh de Afortimer, the official of the archbiahop of Canterbury, to ascertain with the, utmost ceution and cartainty the valeneia of the tenths of all benefices throughout England." Four days later, on 18 October, 'an unbeard of writ,' in the opinion of Mattherr Paris, prent forth from the chancery, ordering en inquisition to be held on every manor belonging to a religions house by the reeve of the place and four trustworthy men. They were to make a return of the number of plonghs on the demesne lend, the number of castomary tenants, the value of their works and rents, and the yearly value of the manore, deducting necessary expenвe日." "Nothing good could come of it,' was the comment of Matthew Paris.

In 1255 Rustand, a papal chaplain and nuncio, accompanied Peter Aquablanea, bishop of Hereford, to England to carry out the papal mandates. He sent ont letters to the heads of religions houses, notifying that according to the interpretation of the apostolic

D Barl A8. 1005, fi. 1-4, Brit Was

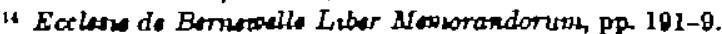

us Ropistram Nalmesberzonse, ad. J 8 . Brower and C. T. Nertin (Rolls Serien), 1. $208-71$.

* Aroudel dIS. 80, foL 155 v., Collegpo of Arme. I em mach Indebted to Blr Alfred Seokt Gatty, Gartar, for kindly giving me ecoest to thbs NS.

1 Cotton SIS, Olendius, D. xi. tol 278 v., Brit.dun.

1- Roles Gascons, ad. F. Nichol, 1. 460, no 8727 I am indebted to Mr Habert Hell for this and the following relarence.

" Mlatth. Parta, T, 104. 
oee baronies and manors were included under the proventus ecclesiastici, and tenths on the proceeds obtained from them in 1254 were to be paid up before the feast of the Purification 1256. $\mathrm{He}$ ordered a ner assessment to be made by archdeacons and raral desns of the temporalities and spiritualities, insisting that it should be not only tusta but rera, and that no portion, however small 'in weight, number, and measure, in lands, meadows, pastures, pannage, gold, silver, grain, liquor, works, free services or villeins' customs, in loaves due at Christmes, in chickens, eggs, or any other ecclesiastical dues whatsoever' should escape assessment." According to the monk of Burton the beneficed clergy of every diocese in the kingdom presented a remonstrance, and he entered the articles drawn np by the clergy of the archdeaconry of Lincoln and of the diocese of Coventry and Lichfield." Rustand was obliged to consent that the tenth for 1256 should be paid on the Norwich texation. In 1256 howerer Alerander IV ordered the archbishope and bishops to comply with Rustand's demand for an assessment of their own bona and those of the religious houses sabject to them. ${ }^{13} \mathrm{He}$ sent another mandate to all archdeacons throughout Englend, requiring them to make a night and fair assessment of all ecclesiastical benefices, unfettered by the antequa taxateo, that the king might get his tenth on the true valuation." Rustand produced the papal letteis at an assembly of archdeanons on Pession Sunday, 1256."

The king and Rastand upparently had strong reasons to suspect thet the Norwich taxation was intimately connected with the antiqua taxatio, although the rural deans had imstructions to disregard former assegsments of benefices. In the assessment of the rural deanery of Norwich in $\mathbf{1 2 5 4}$ it was noted that there were a number of benefices in the city which had never been assessed or entered on any list, on account of their porerty. Is In the opinion of Thomas Wyies, the chronicler of Oseney Abbey, the Norwich asseasment was an abominable innovation on the antiqua taxatio." The date of the antiqua taxatio cannot be determined with any certainty. Wykes stated that in 1226 the clergy granted a six. thenth of their benefices on the antiqua taxatio," and the compiler of the 'Annals of Oseney,' from whom Wykes appesars to have borrowed the earlier portion of his mork, wrote that the sixteenth was paid on the assessment on which churches were assessed when

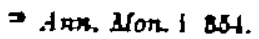

3 Ibod pp. soo-s

"Ibid pp sot-80.

- Foediva, L. 848.

"Ibid. Through mome confuston Blehop Strbbt in bis Constitutional History, if 18s, steted that the Norrich tnretion was mede in conempenee of this boll, and

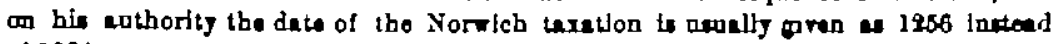
of 1284 .

- Anr. Nor L. B88, 389.

D ArR. JTom. 1r. 825.

to HerL IS. 1005, 111.

M Toid p. 07. 
the twentieth was given to the pope in aid of the Holy Land." That twentieth was given for three years in 1217, and the canon of Dunstable noted that his honse paid on the valuation of trastworthy men, thus suggesting that the method of sporn inquest ras employed at least for the temporalities of the church. ${ }^{\text {*o }}$

In 1265, in answer to the king's petition, Pope Clement IV grented him the tenthe of the spiritualities and temporalities of the church for three years on a verue talor." The'first tenth vas paid in 1266, apparently on the Norrich tarstion, for it was not until 1267 thet the king sent his clerks into every bishopric in England to make a new assessment of temporalities and spiritualities on the valuation of the common people (ptebe), who were anmmoned for that purpose." Immediately afterwards all the bishope compounded with the king for their bishoprics, offering a tenth for three years on the Norrioh taration instead of a tenth for the remaining tro years on the new valuation. They may rell have objected to the dangerons precedent of this aseassment on a verve valor, but Thomes Wykes was 8are that they bad made the bargain to clear a profit for themeelves." Although, on account of their exemption from episcopal visitation, the abbot and convent of Bury 8t. Edmands asually had no dealings with the bishop of Norrich, on this occasion they entered into the composition, becsuse they could deal more freely with his tax-gatherers than with those of the crown." They also covenanted to pay for three years on the Norwich taration for some of their menors and charches, but on a number of manors which had never been esed in the Norwich teration they paid for two years on the essessment of the king's clerks. They secretly paid the bishop's tax-gatherer twenty marks that their property within the bounds of the town of Bury might escepe taxation, but the king's tax-gatherers got hold of the assessment, which was $100 \mathrm{l}$., and they had to pay on it. At a meeting of convocation of the province of Canterbury in 1269 a protest was made in the name of the clergy against the intolerable barden of this last tenth; it was gtated that churehes which had been asseesed at 10 marks in the Norwich taxation had been pat up to 26 marks by the king's clerks, and others in proportion, and that if through poverty rectors and vicars were unable to meet the tar-gatherers' demand on the first day they afterwards exactod the tenth on the new assessment."

At the council of Lyons in 1274 Grogory $\mathrm{X}$ demanded the tenths

Aner. 2rom tr. 87.

- Ibrd. 1. 64, 11. 82.

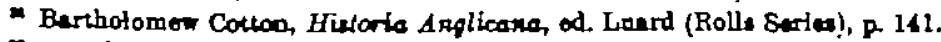

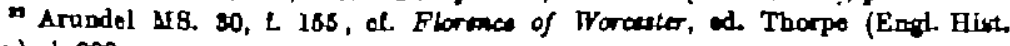
Soe.), 11. 202

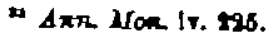

"Arandel MSs. 80, t. 156

- Willins, Comeilia, IL 19. 
of the charch, according to a verus valor, for sir years for the Holy Land, and on 20 September 1274 he appointed Master Raymond de Nogeriie, a papal chaplain, and Friar John of Darlington to act a collectors in England. ${ }^{x}$ John of Daxlington, who became archbishop of Dublin in 1279, was a distinguished Dominican friar; in 1256 he was a member of the.king's council, and in 1258 he was chosen as one of the representatives of the crown to draw up the Provieions of Oxford with the berong' representatives." The procedure of the collectors was resented by the church, and John of Pontoise, archdeacon of Exeter, Henry de Hauecle, and Walter Lochlade, probably afterwards precentor of Exeter," were chosen as envoye of the clergy of the realm to lay their complaints before the pope.* They told him that the collectors summoned three or four persons from each college or convent to London to take an osth as to the value of their possessions and compelled them to pay the tenth then and there; further, in direct contravention of the instractions to collectors, which had been drawn up by Bartholomew, bishop of Grosseto, $w$ they exacted the tenths from lasserhouses, hospitals, very poor religious houses, from beneflces whose annual value did not exceed air marks, and from the ealaries paid by chapters, canons, and rectors to ncars, priests, clerks, and parochial chaplains. They made no ellowance for the expenses incurred by the clergy in cultiveting their lends and collecting their income, and their clerks ased benefices at the maximum value. The cellarer, sacriet, cemerarius or chamberlain, and two other monks of Bury St. Edmunds swore that the yearly value of the abbot's possessions was 1000 ., while the temporalities and spiritualities of the convent amounted to 1608t. 8s. 2d.41 Evesham was assessed by its proctors at 1000 marks, "4 Cirencester at 500l., Tewkesbury at 394l. 10s. 6d., Worcester at 214l. 5s., 8t. Auguatine's, Bristol, at 210t. 13s. 7d., Lanthony by Gloucaster at 101L 19s., Great Malvern at 75l. 2s. 4d. The proctors of Petarborough ${ }^{3}$ and St. Albens 4 were unpilling to swear, and both houses were 2000 markesed at The collectors rejected the oath of the Augustinian canons of Dunstable and compelled them to pay on 400 marks." Barnwell was eseeseed at 500 marke."

- Blise, Cal of Papal Latlore, i. 149.

- Duet. of Nat. Biogr. xir. $61 \mathrm{t}$

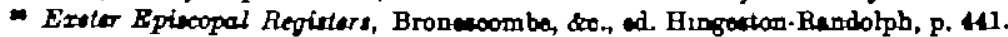

- Cal of Papal Lution, L. 152.

- Berth Cotton, Hid Argl. p. 191.

$"$ Arondel MS. 80, t. 163; of Nomorials of St. Edmand's Abboy, ad. T. Arnold (Rolls Berioe), iit 82.

a Horcatar Epiccopal Reguter, Gified, ed. J. W. Bund (Wore Hite Boc.), p. 148 .

- Ohronicom Patroburpune, ad. T Bteploton (Cemden goc.), p. 81.

4 Walnghem, Gesta Abbaturn, ad H T. Blley (Rolls Seriea), L 168.

- Ans Mor IiL 267.

- Liber semorandorume, p. 199. 
John of Darlington had great difficalty in collecting this tenth, and indeed it is donbtful whether it was ever paid up in fall. He coerced the convent of $8 t$. Albens into making regular peyments by excommunicating the sbbot and chief monks, ${ }^{17}$ and took similar messore egainst the prior and convent of Christchurch, Canterbory. As late as 1882 a number of monasteries in the diocese of Worcester were in srrears with the grester part of their peyments." In 1278 Edrard I hed sent John of Darlington, with other envoys, to Rome to esk for a grant of these tenths for a crusede, ${ }^{\omega}$ and Nicholas III consented to make it at some future time if the king would publicly toke the oroes and honeatly purpose to set out. In 1288 Edward I seired the tonths which had been collectod, but was compelled to give them up."

Foiled in this ettempt, in 1284 he negotiated with Pope Martin IV for a fresh grant of tanthe of the spirituslitios and temporalities of the church in England, Bootland, Ireland, and Wales, according to a vorus valor. Martin IV and his successor, Honorius IV, were willing to make the grant for a term of years, on condition that the hing should publichy take the oross and fix the date of his departare for the Holy Land." On 7 Ootober 1289, after receiving a promise from the king that he would ont in three years, Nicholas IV consented to order the tanths for six years to be collected by ecclesiastical persons according to the a sesesmont, method, and form ordained by the holy see." $\Delta \theta$ there were reported to be valuations of a diverse aharactor in the two kingdoms of England and Scotland and in Ireland and Wales, on 18 January 1290 the pope agreed that the tenths should be taken iwate verwm valorem, ${ }^{H}$ a concession of the atmost importance to Edward I, for in 1291, in epite of the asessment of 1274, the clergy would only consent to pay a tenth on the Normich taration." On 18 May 1290 Nicholas IV notified that the collectorg would observe the conditions imposed on John of Darlington and his colleague in 1274."s Ten months later, on 18 March 1291, he appointed Oliver Sutton, bishop of Lincoln, and John of Pontoise, bishop of Winchester, to collect the tenths for six years from 24 June, on the anderetanding that the king would set ont on that date in 1293." In another boll, dated a fortaight later, he eupplo-

- Waleinghem, L. 188 1. $10,28$.

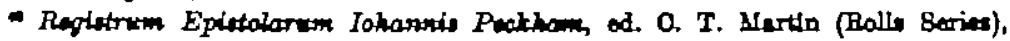

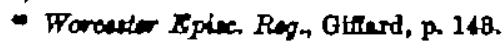

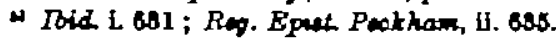

- Fondora, L. 800.

- Mbid. p. 714. In the prefece to P. Nich Trx. the deto in giren en 1988, spperently

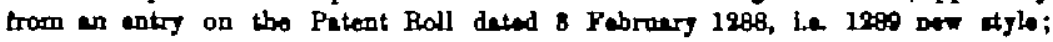
cf. Fonders, L 700.

4 Toid. p. 725.

- Fondcra, L 752.

4 Berth Cotton, p. 188.

* Berth. Cotton, pp 188-7, 191-8. 
mented bis previous instruction to the biahop: : they were ordered to make the essessment themselves or to eelect diecreet persons to act for them, and also to appoint collectors in the different dioceses with the advice of the ordinaries and other discreet men." The assessment was to be a vorwe valor, bat with the reservation that the taration ahould be borne by churches and their rulera without grave inconvenience.

In obedience to the papal mendate in 1991 the bishope of Lincoln and Winchester eent instructions to the bishops of England and Wales to choose representative clergy to aseses the vorus valor of all benefices in their dioceres." In the five arahdenconries of Oxford, Buchingham, Bedford, Huntingdon, and Northampton, except the deanery of Rutland, the esessors were Mester Ralph de Bokingham, rector of Morton, and Richard de Appeltre, rector of Gilling; ${ }^{\infty}$ in the archdeaconries of Suffolk and Sadbury Richard, rector of Bnailwell, and Richard, rector of Button ; ${ }^{n}$ in the diocese of Ely Master Guy of Coventry, the bishop's official, and Ralph of Fotharingay, archdeacon of Ely ; ${ }^{*}$ in the archdeaconry of Heroford Mester John de Chandos and Bimon de Batarleye; ${ }^{\circ}$ in the archdeaconry of Coventry Thomas de Staundon and Pioger called Batan; ${ }^{\text {H }}$ in the city and diocewe of Durhem the vicars of Hartburn and Aycliffe; in the diocese of Carliale Richard of Whitby, archdeacon of Carlisle, and Adam of Levington, rector of Bkelton. The assessors mede their return on the oath of rectors, vicars, and parochial chaplaing ; 4 and it oeems probable that a epecial chapter ras summoned in each rural deanery for that purpose, and that representatives of the chapter ware summoned to meat the esesersors. The charches belonging to the priory of Bt. Neot, in the deanery of Bt. Neot, archdeaconry of Huntingdon, were eneesed by the rectors of Morton and Gilling, in the parish church of $\mathrm{St}$. Mary at Huntingdon." In the diocese of Bangor it is stated in each rural deanery thet the return was made by the dean and other Bworn trustworthy men of the deanery," and in the diocese of Durham by three juries to the assessors at Newcastle-apanTyne in December 1291." Bartholomew Cotton hes chronicled the important fact that the assessment of benefices pan made rino commixtione alicuius laici. It should be noted that, except in the diocese of Carlisle, the verne valor was almoet invariably roturned as a number of marks or aimple fractions of a mark.

The of spiritualities was sabject to revision by the

\footnotetext{
- Barth Cotton, p. 180.

- Moid p. 198. - P. Wich Tax p. 80.

- Aroudel M8. $10,1.180$.

- Clerical Babadia 68/21, P.R.O.

“ P. Nheh Tax. pp. 211, 814, 818.

- Cottan MB., Fantion, A. Iv. 1. 220.

- P-Nich Tar. pp $290,991$.

- Libor Lomoromdornim, p. 200.

- Berth Oatton, p 120.

- Ibld p s14
} 
bishops of Lincoln and Winchester. The Augustinian canon of Dunsteple recorded in 1298 that, "hearing that some benefices were eseessed far below their true value and others far above it,' the bishop of Lincoln came in person to make a ner aseasment, $\infty$ and the herding of the roll for the four arehdeaconries of Orford, Bachingham, Bedford, and Nortbampton, in the diocese of Lincoln, testifies that it contains the reassessment of some churches made by the bishopes ${ }^{\text {to }}$ The ersessment headed Snailwell, written in the margin of the Norwich taration for the archdeaconries of Suffolk and Sudbury in the Liber Albus of Bury, " was the original return made by Richard, rector of Snailwell, and Richard, rector of Button, in 1291," and the assessment of a comparatively smell number of benefices was afterwards increased by two or three marks, rarely more, and for a few it was lorered.

Were these returns of spiritualitie a rerus calor according to the terms of the papal bull? Did the clergy matre a new assessment of their glebe lands and stock, of their tithes and offerings? The Norwich taxation and the "Nonarum Inquinitiones' 72 throw some light on this question. In the 'Nonerum Inquisitiones' of 1841 pariahioners from every parieh declared on oth before the venditora and asesers of the cromn the true value of the ninth of corn, wool, and lambe for the pest year; then they stated the value of the charch according to the taration of Pope Nicholes, and when the ninth did not exceed that amonnt they gave as a cause thet the glebe of the church, the tithe of the hay, and other tithes and offerings had been reckoned in the valuation of the charch in 1291. In some cases they merely added that these items accounted for the difference, but in eeveral counties they set down the value separately of each of them. The inference is that they had before them the original valuation of the church in 1291, and gave the items from it, for it cannot be supposed that with no instruetions to that effect they undertook the further trouble of inquiring into the current value of those items. A number of the 'Nonarum Inquiaitiones' therefore contain the original returns of the value of benefices for the taration of Pope Nicholas, with the exception of the eeparate values

- Anar. Mon IIL 882.

* P. Nuch Tax. p. 10.

"Hart. M8. $100 \mathrm{~s}$.

$n$ Tho Bnell woll aneriment hes been recently attributed to the fourtoonth centory, and the statement he beon made that 'it correpponds fairly eboely In the ralae

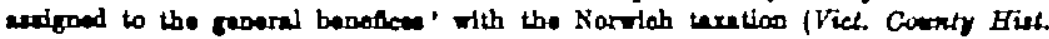
Suffalt, i. 14). Howerer John of Everisden th quito clons: ' Dominus papa domico

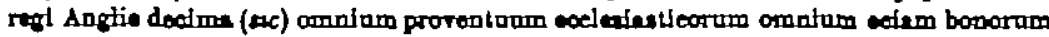

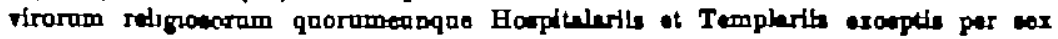

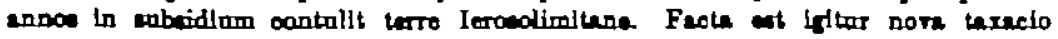

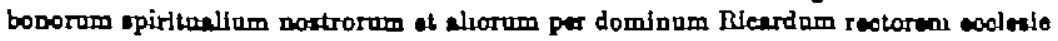

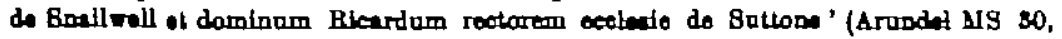
1. 180 v.; ef. Hart. 18. 8977 , 1. 86).

"Pablinhed by the Becord Commtaion, 1807. 
of the tithes of corn, wool, and lambs. A comparison of the Norwich taxation, the taration of Pope Nicholas, end the 'Nonarum Inquisitiones' for a number of churohes in the archdeaconry of Budbury has given some interesting results. Creeting All Beints was asseased at 9 marks in 1254, at 15 marks in 1291 , and the tithes of hay, flax, and hemp, and other small tithes and offerings amounted to $6+$ mark . Creeting $8 \mathrm{t}$. Petar wes assessed at $5 \mathrm{l}$. in 1254, at 10l. in 1291 , and the tithes of hay, flax, and hemp, and other small tithes and offerings amounted to $4 \mathrm{l} .18 \mathrm{~s} .7 \mathrm{~d}$. Rougham was aseased at 26 marks in 1254, at 60 merks in 1291, and the tithes of bay, flax, and hemp, and other amall tithes and offerings amonnted to 82 marks leas 8d. Irning was asosed at $42 l .13 \mathrm{~s}$. $4 d$. in 1264, at 68l.6s. 8d. in 1291, and the tithes of hay, flax, and hemp, and other small tithes and offerings amounted to 20l. 11s. 5d. The rectories of Btow Bt. Peter, Btow Bt. Mary, Haughley, and Newton were assessed at the same amount in 1254 and 1291, while the corresponding vicarages rose from 2 marks to 8 , from $30 s$. $6 d$. to 5 marks, from 30 s. to 6 t marke, from 40s. to 5 marke. This evidence suggeste that for a number of churches the small tithes and offerings were not assed at all for the Norwich texstion, a theory which is supported by the opposition of the clergy in 1255 to the new assessment in which Rustand propoesd to allow no exemption upon eny portion, however small." For a number of other benefles in which the tithes of hay and other emall tithes and offerings constituted an important part of the revenues the evidence again suggeste thet these items were ustally, though not invariably, assesed in 1254, and in coneequenoe there was no change in 1291, as at Finborough Magne, Buxhall, Bradfield 8t. Clare, Little Livermere, and Tostook. The evidence aleo suggests that in the diocese of Norwich the Norrich taration res ueed as the basip of the taration of Pope Nicholas.

In the opinion of the canon of Bernwell the archdeacon of Ely and the bishop's official made a trustworthy and carefal aseesement of the epiritualitios of the diocene." $\Delta$ comparison with the Norwich taration "showa that the assessment of only a small number of benefices remained the same, while on the higher arsesemento there Was a very considerable increase, Heddenham rising from 60 marks to 120 , Leverington with the vicarage from 80 marks to 127 without it, Cottenham from 39 marks to 60 , Over from. 25 marks to 58 . The returns of the "Nonarum Inquisitiones' for Oambridgeshire are very brief, and, as the aseasment of the varions tithes and offerings is not specified, no deductions can be drawn from them.

Evidence illustrating the difference betreen the actual revenues

"4ar, Mon, is 861-3. - Liber Nemoradorwm, p. 200.

" Ibrd pp. 191-9. 
of benefices and their essegement in 1291 can be glenned from many scattered sources The following list $"$ shows that the total receipts in 1898 from a number of churches appropristed to the monastery of Darhem were much higher than the assesement, although the recoipts represented a net inoome and no provision for a vicar or parochial chaplain hed to be deducted from them.

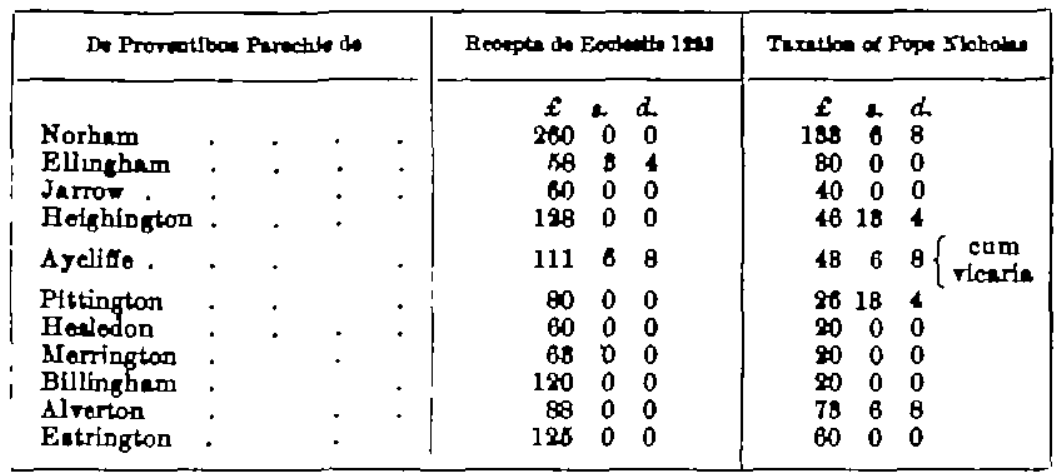

In 1801, when a complaint was made against Godfrey Giffard, bishop of Worcester, because he had extorted $80 \mathrm{~L}$ for firstfruits from the rector of Great Compton, whereas the rectory wias only asesed at 12l., the bishop replied that the charch of Great Compton was worth 50 marks, whereol his ministers received $20 l$. for the firstfruite bold to the rector, according to the tenor of the apostolic privilege." In a record of the benefits conferred on Malmesbary by Abbot William de Colerne (1260-96) the church of Purton is set down es worth 50 marks a year to the honse, although in the Norwich taration the abbot and convent's portion of the revennes rase assessed at $19 l .64 .8 d$, and at $16 l$. in 1291 ; and the church of Kemble as worth 40 merks, whereas the abbot and convent's portion rag aseesed at 18l. in 1254 and at 11l. in 1291." From the lower assessment of these two charches and those of St. Mary and St. Paul at Malmesbury the recond editor of the Regioter of Malnessbury appears to have drawn his deduction that where the two valuations do not tally the earlier is generally the higher, ${ }^{\infty}$ a statement which requires some qualification, for the esesement of the temporalities was higher in 1291," and in the case of the four churches it is probable that perpetual vicarages hod been created between 1254 and 1291 , thus diminishing the abbot and convent's portion of the revenues. In 1875 the monks

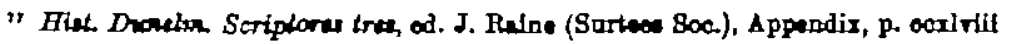

ro Wore. Eprea. Reg, Gifiard, p 6.50.

- Rog. Matrastowionse 1. 200-73. 1L. 858.

- Iotd is p.rim.

1) Iord L 208-71. 
of Bary 8t. Edmunde ewore that the yearly value of the revenues from the appropriated ohurch of Pakenham was 60 marks, "n and yet in 1891 the rectory only asesed at 38 marks. ${ }^{83}$ In 1809 the abbot and convent of Winchcombe appropriated the charch of Enstone, in Oxfordshire, and, though essed only at 40 marke, in 1389 the convent reckoned in ordinary yesrs on dra wing 80 marks from it, and apparently it had yielded about that income to the late rector, for when he resigned in favour of the monastery in 1809 he stipalated for a pension of 80 marks until bis death." Betreen Micheolmas 1886 and 1897 the prior and convent of Ely received 177L 12s. 8fd. from the charches of Melbonrn, Stapleford, Whittlees, Lakenhesth, Witchsm, and Haurton, which were aseesed only at 110l. 18e. $4 d$. In 1241 the abbot and convent of Jumieges reckoned to pay 89 marks a year out of the revenues of. the church of Chewton, in Somerset, meintsin a vicer and several chaplains, and make a profit; yet in 1291 it was only aseseod with the vicarage at 68l. 19s. 11 $d$., while again in 1416 the prior and convent of Bhene Charterbouse farmed the rectory to the dean and chapter of Welle for 45l., excluaive of a pension of $256.6 \mathrm{~s}$. $8 d$. charged upon it. $*$ In 1820 the vicar of the prebendal ahurah of St. Decuman's complained that his portion of 61. 4s. 61 d. wonld not suffce for the support of himself and tro chaplains, and the reyenues then emounted to 53l. 15s. 4d., wes only at $28 \%$. In 1898 the dean and chepter of Wells fired the farms of several churches appropriated to them at a price considerably higher than their value in the taration of Pope Nicholas."

\begin{tabular}{|c|c|c|c|c|}
\hline \multirow[b]{3}{*}{ Congresbary } & \multicolumn{2}{|c|}{ Farm to 1289.} & \multicolumn{2}{|c|}{ Tax P. Nlob. } \\
\hline & $\varepsilon \approx$ & a. d. & E2. & d. \\
\hline & 480 & $0 \quad 0$ & 2818 & 4 \\
\hline Chodder & 8618 & 81 & 2818 & 4 \\
\hline Molety of Whitehuroh & is 6 & 68 & 1418 & 4 \\
\hline Btogramber & 600 & 00 & 1118 & 4 \\
\hline Lydened & 200 & 00 & 88 6 & 8 \\
\hline Mudford and Lorington & 8618 & 84 & 28. 18 & 4 \\
\hline
\end{tabular}

An instraction given by the bishop of Norwich to the raral deans in 1254 supplies a clue to the difference between the net revenues of a benefice and its absessment: ' if it seems fair to you we will that every one whose church is farmed shall ansprer for the tenth according to the amount of the farm which he receives.' 2 In 1340 the parishioners of Chesterton, in Cambridgeshire, awore

- Aroudel M8. 80, 1213.

* P. Nick Tax. p. $119 \mathrm{~b}$.

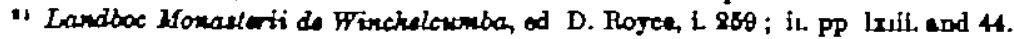

- Bolln of Trearorern and Camerartun penes D. and C. Ely. I am muoh indebted to Arabdecon Chepmen for kindly giving me acoese to then rolle.

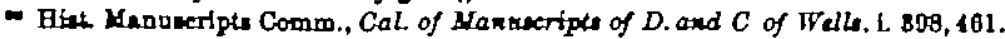

- Ibed. p. 888 .

- Ibed. p. 200.

Anr. MON. L BaB 
thet before the reign of Edward I the charch was asesed at 46 . and was farmed at that amount."0 The same principle was conceded in 1274 and 1291, with the reservation that a vicar abould not be regarded a farmer of the rector's portion and thus escepe payment on his own portion." $A$ number oi the "Nonarum Inquisitiones ' contain an extent of the glebe or endorment of the charch, showing in every case that it was assesed only at the rental per acre. As the asesentente 1264 and 1281 were made entirely by the clergy for pnpopular taxation it may be assumed thet they retarned the verue valor of epiritualities in 1291 at the lovest amount at which benefices could be farmed, and were justified by the pepal instruction that the taxation might be borne without grave inconvenience. Although it was anneus in the thirteenth century to farm vicarages they were assessed on the seme principle, and thas the difference between the value of a vicarage at its ordination and in the taration of Pope Nicholas can be to vome extent expleined. In 1871 Godfrey Giffard, bishop of Worcester, ordeined that the vicar of Sherborne, in Gloucestershire, should receive not less than 10 . a year, without reckoning his manse, yet in 1291 the vicarage was returned as worth $5 l^{\text {." }}$ Thomas Cantilupe, bishop of Hereford (1276-83), granted tithes and offerings to the vicar of Charcham which were valued at 11l. 6s. 10d., yet in 1291 his portion was ansessed at $5 \mathrm{l}$ 6s. $8 d . " 3$ The vicarage of Dymock res fired by Peter Aquablanca, bishop of Hereford, in 1247 at 14 merks, yet in 1891 it wac returned as not worth 6 marke."

In the conree of 1291 the bishops of Lincoln and Winehester appointed discreet persons to essess the temporalitie of bishoprics and all religious houbes except those of the Templars and Hospitallers, and of poor nunnerie and hospitals. Richard of St. Fridentide, archdeacon of Buckinghem, and Robert Luterel, canon of Balisbury, acted for them in the dioceses of Norwich and Ely; "Mester John de Walecote and William de Bteynton in the five srahdesconries of Backingham, Oxford, Bedford, Huntingdon, and Northampton ; to Master Peter de l'lle, arehdesoon of Exeter, and Adem de Haston, rector of Beckinghem, in the dioceses of Darham and Carlisle; and in the archdeaconries of York, Cleveland, and the East Riding." Bartholomer Cotton, the monk of Norwich, has recorded in precise terms the procedure of this inquisition." In every rural deanery

- Lay 8abeddila 81/17, P.R.O.

" Berth Cotton, p. 192.

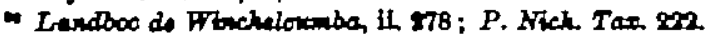

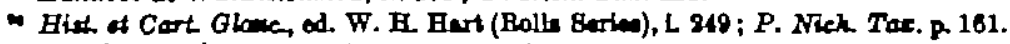

4 Add Y8. 184B1, t. 16 (Brit Hate); P. Nich Tar p 161.

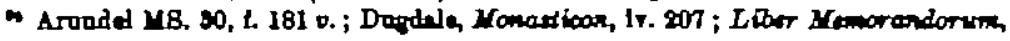
p. 200.

W P. Nich Tas. p. 18.

"Ibid. pp. 805, 818, 820 .

- Berth. Ootton, p. 198. 
the essors cited all abbots, priors, and heads of religious houses bolding property in that deanery, the bailiffe and reoves of the menors of bishops and religious houges, the rector or vicar and pariah chaplain and four or six men from every vill in which the manors ware situsted, and inquired from them on oath the verus valor of the temporalities of the church. Cotton teetifed that, in spite of the evidence obtained at the inquisition, the bishops and their asors, Richard of St. Fridesuide and Robert Laterel, doabled, trebled, and quadrupled вome assessments. Concerning these same aseagors the canon of Barnwell wroto-

Walking in enry end not in the ray, led by what opirit I lnow not, they burdened all the religions beyond mesoure; refuning to pat faith in the outh of olerts and laymen, they forced tbe relligious to inear to the vorss valor of their tomparalitien, to put them in writing and theal them with the ofers of their chaptern. And nevertheless these malevolent anesson axcoeded the atatement of the religions and essensed at their own will, and in many pleces they doubled the verus vator. Wharefore the bishopos knowing their malice from the complainte of many, ordered a now essessment of certain temporalities by other trust worthy persons, and reduced other essesuments of their orm wisdom."

Bartholome Cotton recklesely implicsted the bishope in the misdoings of the bessors, but the records of Bury 8t. Edmands bear witness to a reasesent in the diocese of Norwieh in 1298 by Afarter Thomas of Scarning, archdeacon of Suffolk, and Master J. Fleming. ${ }^{100}$ The assessment of the cellarar's temporalities in Suffolk was reduced from 820l. 15s. 8td. to 665l. 7s. 4td.; the sacrist's temporalitie in Norfolk and Baffolk from 189l. 84. 4d. to 169l. 1s. $4 \frac{1}{d}$.; the offerings at the shrine from $100 t$. to $40 t$. ; $^{101}$ the handred of Lackford from 9l. to $1 l^{100}$ In one of the cellarer's registera an entry was made of the grievances of the abbot and convent concerning the excessive aseessment of the cellarer's temporalities in $1891 ;^{103}$ for instance, in the manor of Mildenhall the aesesers made no allowance for a charge of a pittance of twenty shillings and a salary of trenty shillings to a cheplain, and they made the cellarer pay trice over for the abbot of Battle's charge on the manor of twonty marks, and their aseesament ras thus 14h $5 d$. higher than the communis patrie taxacio, which was presumably the sworn essessment of the witnesses whom they had called.

- Liber Nomarendorum, p. 200 .

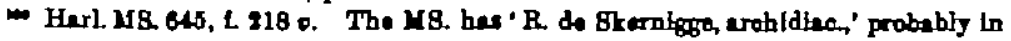

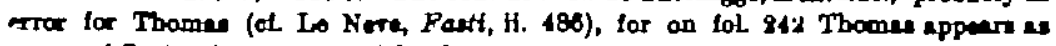
rector of Botton in arror for Bicherd.

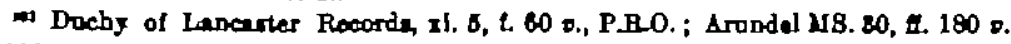
to 1890.

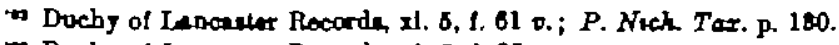

m Duchy of Iemenaler Rocords, xi. 6, $L$ 88. 
The table on the opposite page show the coveral asesements of the principal menors in Suffolk from which the cellarer of Bury 8t. Edmonds dren his revenues.

The instructions to collectors in the papel bull ${ }^{104}$ suggest that the asesement would be based on the manorial account roll and calculated on an average for a number of years. From the total reosipt a deduction wonld be mede for the strictly necessary rorking expenses of ploughing, cultivating the soil, and gathering in the truite. This was usually a considerable sum, as wages of labour, food for customary tenants, provender for stock, repairs of carte and tools pould be incladed, but no allowance was to be made for new buildings or the maintenance of those alteady in existence, or for the cost of making dykes, or for any other improvements to the soil. Woods and fisherie were not to be sosessed unless a profit on the sales was a usual item of the receipts. Important deductions were to be allowed on the item staurum expenoim; fish, beasts of the warren, fruit, and vegetables were not to be tured if consumed by the bishop or by the religious, or given as presents without intention to defraud. Lands or rents granted for the purpose of providing pittances were to be exempt. In estimating the profits of manorial courts the salaries paid to judgee and officials prior to the papal grant of the tenth might be deducted, but nothing for any allowance of food and clothes. The expense of castle-gard, a considerable burden on some of the grest Benedictine housen, was disallowed. When a priory or manor was farmed out the tenth was to be paid upon the rental if it had been fixed at a fair rato without special regard to other circumstances.

The returna for most of the dioceses are very brief, and notify only the amount of the assesement of the temporalities, information sofficient for the tar-gatherer, but uttarly baffling to a stadent in search of the underlying principle. However very foll retarn. wero made for Hereford, Coventry and Lichfield, and the Wolsh dioceses. These shor thet the form of the aseessment was not borrowed from the manorial account roll, with ite profits from the ale of corn and other produce, but that it epprorimated more closely to the manorial extent. In assessing the value of the demesne land of a menor or grange the sprom inquiritors avoided the difficulty of interpreting ' neceasary expenses' and of belancing profit and loes by reckoning arable, meador, and pesture as worth Bo much a carucate or an acre per annom at the current rental of the menor. Rents, mills, profits of roods, fisheries, and dovecots, tines and perquisites follow in due order, and labour earvices were entered only when they hed been commated for money. There is 


\begin{tabular}{|c|c|c|}
\hline \multirow{3}{*}{$\begin{array}{l}\frac{7}{8} \\
8 \\
8 \\
8 \\
8 \\
8 \\
8 \\
8\end{array}$} & 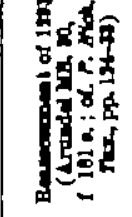 & 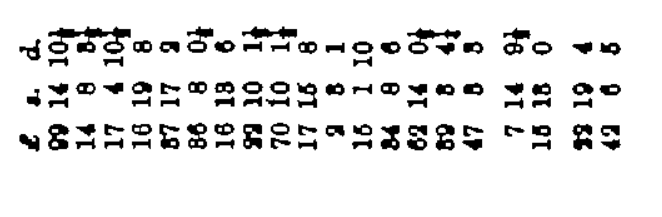 \\
\hline & 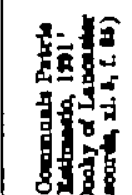 & 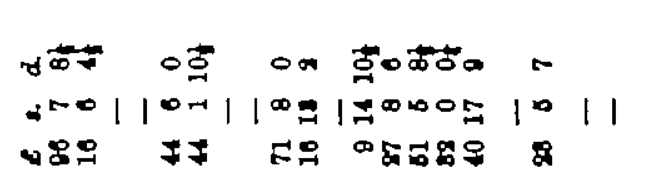 \\
\hline & 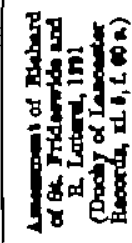 & 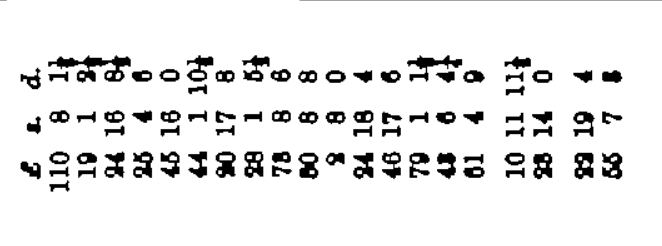 \\
\hline & 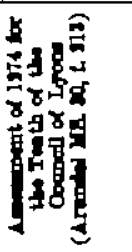 & 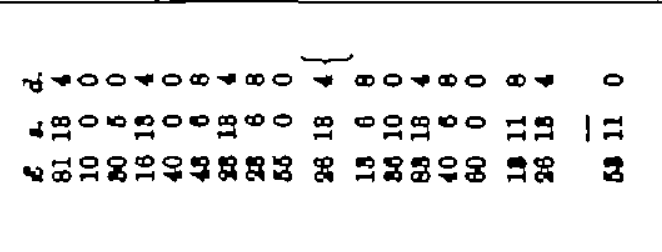 \\
\hline & 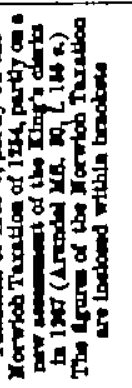 & 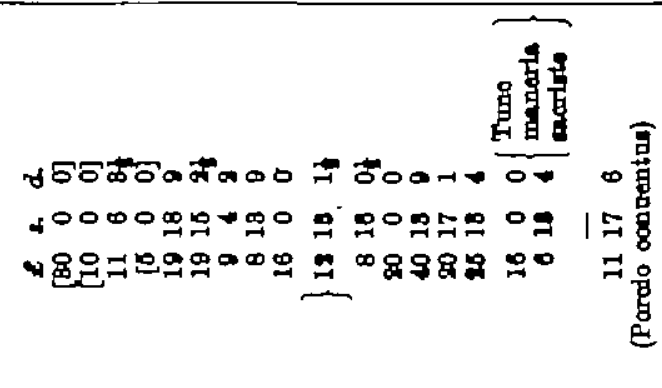 \\
\hline & $\begin{array}{l}8 \\
8 \\
8\end{array}$ & $\begin{array}{c}\ldots \ldots \\
\ldots \ldots\end{array} \ldots \ldots \ldots$ \\
\hline
\end{tabular}


clear evidence that in this aseasment only flocks and herds were treated as movables; these were valued separately on the sole items of their yearly increase and of the sale of milk and cheese, for wool, woolfelle, and hides were subject to the indirect taration of the eustoms. In the Welsh dioceses cows and meres were valued at a shilling a head anleses they numbered over a hundred, when the cost of custody was slightly diminished; e.g. 106 cows belonging to the abbot of Con way were assessed at 6h.6s. Sheep appear to heve been valued at between threepence and fourpence a head.

This anslysis of the only on the rental and that probably a minimam-at which menors and granges might be let, although the biehope and the religious then farmed the greater part of their own lands at a profit. If this theory may be accepted the verus valor of the taration of Pope Nicholas is closely akin to the valot of Domesday Book, concerning which Professor Maitland prote, 'On the whole the valet of Domesday Book, so far as it is precise, seems to me an answer to the question, What rent would a firmarius pay for this estate stocked as it is? But there are many dufficulties.' ${ }^{103}$ His comment that in Domesday Book ' we are baffled by the makebelieve of ancient finance' 100 is equally true of the taration of Pope Nicholas. It is clearly mislesding to represent the assesament of the temporalities of a religious honee as its income, either grose or net, from that source. Moreover the evidence concerning ecclesiastical revenues, acanty though it is, shows that these do not correspond even approximately to the assessment. In the roll of the bnrsar of the monastery of Durham for 1298 the receipts were 374.1l. 9s. 10 d., inoluding the payment of errears of 1368l. 1s. 8d.; in 1295 the receipts again amounted to $9975 \mathrm{~L}$ 16e. 11 $d d$, and in 1297 to 8626 . 5s. 5td.; ${ }^{107}$ and although the cellarer and the master of the garners drew almost the whole of their revenues from the burser, the eacrist, chamberlain, and hosteller had their own endowments, amounting probebly to another $400 \mathrm{~h}$ : ${ }^{100}$ yet the temporalities of Durham were aseat at 620l. ${ }^{103}$ in the taration of Pope Nicholas, and the spiritualities at under 700k., not reckoning the charches in Scotland and the procoeds of Coldingham Priory, which brought in together 149l. 5s. 8d. in 1899. The barony of Bary St. Edmunds was aseesed at 766l. 13s. 4d in the taxation of Pope Nicholas, yet from 21 April to 5 November 1279 the net receipt of the escheators Fas 8996. 7s. 0fd. In 1292 the receipte of the eacrist of Ely amounted to $240 l$. 13s. 5d., and the charges, such as peyments to the

as F. W. Mestlend, Domadoy Book and Beyond, p. 144.

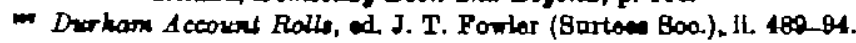

in Ibad rol. L. - P. Nich Tax p. 318.

16. Pipe Roll, 9 Ed. I, m. B. Thin mon Ineloded 100 marke tram the abbot's exwortar. 
vioar of Wentworth, \&c., did not exceed 25l., yet the tenth paid wes under 15 ${ }^{11}$ The spiritualities and temporalities of the sacrist of Bary St. Edmonde were ased at 8092 1s. 4 d., ${ }^{13}$ yet for the half-year aftar Michaelmas 1299 bis receipts were 184l. 14s. 10td., and his expenses were 2031. 11.. 2 $d^{113} \Delta$ number of monasteries, inclading many Cistercien and Gilbertine houses, derived a considereble revenue from the sale of wool, which was not aseosed in the taxation, and the list printed by Arehdeacon Cunninghem is of grest interest, for it wes probebly compiled in the latter half of the thirtenth centary and it epecifle the average namber of sacks mold at each house and the price of them. ${ }^{111}$ The temporalities of Winohoombe rere asseged at ander 110L in 1291, and 40 gecke of wool were eold on an average at the rate of 19 marks a seck. The temporalities of Heiles Fere eseesed at 58l. 8s. 11d., and 20 sacks of wool were Bold on an average at prices verying from 10 to 7 mark a seck, according to the quality. The temporalitie of Fountains were asensed at 3561. 6s. Qd,; and the average anle of wool tas 76 sacks at from 21 marks to 9 . The temporalities of Malton were asesed at 2021 . 8s. 5d., and the average sale of wool was 45 eacks at from 17 to 6 marks, and from 1244 to 1258 the receipts from wool amonnted to 5224l. 9s. 3d.14 Other houses which mere not on the list are also known to heve been engaged in the rool trade, among them Gloucester ${ }^{116}$ and Lenthony by Gloncester. ${ }^{117}$

Though the taretion of Pope Nicholas will not reveal the income of the monasteries or of the beneficed clergy it is nevertheless a most valusble reoord. By painfal calculation Bishop Stabbe arrived at the yield of a clerical tonth, and thus spprorimately of the produce of a vote of a tenth and fifteenth. ${ }^{14}$ It is difficalt to calculate aright the different monsateries from the printed text of the taration of Pope Nicholes. The epiritaalities cannot be detarmined, because in the greater number of dioceses the appropriation of charches is not specified; they appear to have been carafully noted in York, Durham, and Norwich, in the archdenconrie of Oxford, Coventry, and Balop, and in gomedeneries of Canterbury, but elsewhere occasionally or not at all. A pepal ball or chartar confirming all the possesaione of a monatery vill cometimes eolve this difficulty. Although the spiritualities of Bory St. Edmunde lay in the diocese of Norwich the assesement

\footnotetext{
II Scoriat Rolls of Ety, ed. F. R Ohapmen, It. 8-18.

18 Arondel Y8. 0, I. 180 o. to 160 \%.

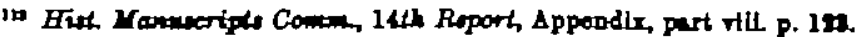

11. W. Oonotngham, Growth of Englich Inductry and Comimore during the

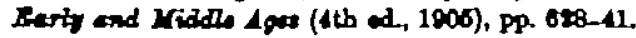

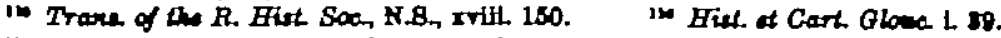

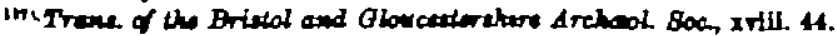

in Btabber, Oontitutional Butory, IL 679.
} 
of them has been recently calculated at $152 l .19 s .4 d .{ }^{110}$ instead of 2021. 18s. 4d., through the omisaion of the charches of Pakenham, Great Barton, and 8t. Luprence at Norwich, and weveral pensions.

The total asesment of temporalities is only a matter of erithmetic, but the text of the taxation supplies no safe clue to the division of property betreen the abbot, convent, and obedientiars of the Benedictine houses. Bury 8t. Edmands is a notable ingtance. In the manuscript of John of Everisden at the College of Arms the essegsment of temporalities in entered onder eperate headings for the cellarer, acrist, and other officers, and an identical list accurs in other registers of the monastery. ${ }^{100}$ The difference between these totals for the three chief obedientiars and the totals recently calculated from the taration of Pope Nicholas is es follow日 :-

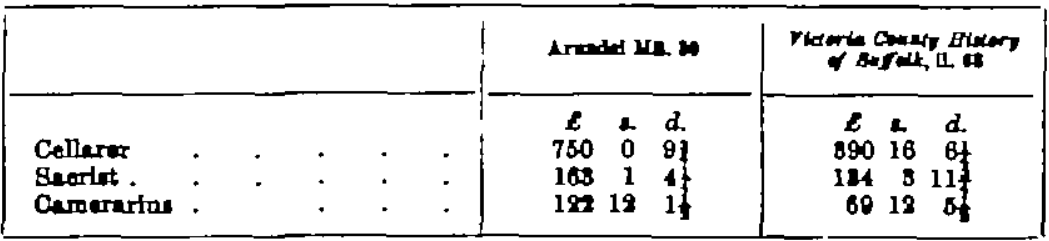

In the printed text of the taration, as indeed in the original rolls, certain manors and rents are merely noted as belonging to the convent; hence the discrepenoy between the ebove figures. If further evidence is needed of the appropriation of those manors and rents to the obedientiars in $\mathbf{1 8 9 1}$ it is found in a charter of Edward I dated 1281, in which he confirmed a distribution of property between the albbot and obedientiars." The abbot and convent rere jointly liable for the payment of tenths, and therefore assegsors and collectors were not concerned to make an exact retarn of the division of the property. The embiguous ' convent' is pecaliarly misleading for Bury, as the common fund was extremely emall and was mainly derived from the contribations of the obedientiars. In The total assesment of piritualities and temporalities of the abbot and convent amounted to 2071 l. 12s. $5 d$., and the total of nearly $1000 .^{12}$ of the most recent calculation is a curions error. The retarn for the prior and convent of Ely ${ }^{214}$ is extremely confased as regarda the division of property; rents in Ely and Cambridge correspond with the eacrist's receipts in 1291-9, bat the grange of Ely and Wentworth, from which he drew 119l., are not assigned to him. The common fund was large

it Vietoris Cownty Hith Sufolk, it

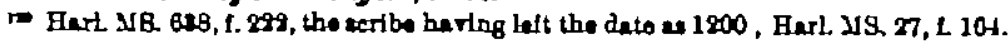

Id Dogdelo, Nonasticon, ili. 166

17 Duehy of Lentaster Recordy, ri. 5, L. 63 v.; Berl. NS. 8977, t. 18

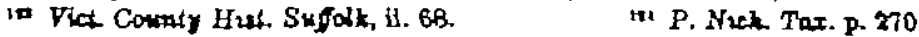


at Ely and was administered by the treasurars, but the property appears to be entered under the prior's name. $\Delta$ list of apiritnalities and temporalities as aseessed in $1291 \mathrm{wes}$ entered in some register of every monastery, and whenever this can be found it will give more accurate totals than those obtained by tedions calculations trom the printed tert of the exchequer manuscript. The assessments for Barnwell, ${ }^{13}$ St. Albans, ${ }^{12}$ Spalding, ${ }^{127}$ Bt. Neots, ${ }^{12}$ and Mesur in may be mentioned as examples. However the regiaters and charters of a grest number of lesser monasteries have now disappeared, and the taration becomes the sole source for their endowments at the end of the thirteenth century. Leper hospitals and other hospitals for the sick poor, nunneries and other communities of the religious who could not live of their orm and were forced to beg were exempt from the payment of the tenth, ${ }^{10}$ and therefore are not entered in the assesement.

The taration of Pope Nicholas is, again, a valuable reoord for parochial and diocesan history if its limitations are anderstood, and statistics are not based apon it rithout reference to other sources. Variations in the returns of epiritualities preclude an exact calculation of the number of parishes and vicarages in a county or diocese. Beneflees not exceoding aix marks were exempt from taration if the rectors beld no other living, ${ }^{131}$ and anless they were appropriated to religious honses; they therefore do not appear in the ordinary returne. For a for archdeaconries and dioceses there are schedules of benefices and vicarager not exceeding six marks, vir. the archdeeconries of London, Middleser, Leicester, Lincoln, Store, Corentry, and Salop, and the diocese of Hereford, Ereter, and Durham. In the return for the archdeaconries of London and Middlesex it is stated that these benefices exced two marks, implying that there were others below that amount, whereas in the diocese of Exeter no ferer than 78 benefices, vicarages, and chapels were assessed at less than tro marks a year, and eight chapels in the city of Ereter were not absesed at all, because their revennes scarcely sufficed for the maintenance of a chaplain. Another possible Bource of error is the eremption of certain spiritaalities : those of the Templars and Hospitallers may be ascertained from the report of Prior Philip de Thame to the grand master of the Hospitallers in 1938, 1 's but those of poor nunneries and hospitals can only be gleaned from registers and charters; for instance, in the deanery of Wangford, in the archdeaconry of Suffolk, Ilketshall St. Andrer, Dketshall St.

in Liber Honorardonwe, pp. \$01-8.

- Cottan MIS, Clandines, E Ir. f. 187.

" Add. Ng. S844, $t$ 94.

in Cotton MB, Fantine, A I. II. 85 v to 87

iv Egaton \$Y8. 1141, 1. 177 च.

- Berth. Cotton, p. 192.

in Iord

is Inights Haspitallors in England, w. I. B. Larting (Oander Soo) 
Larrence, and Bungay 8t. Thomas are altogether misaing, while only the vicurages of All Saints Mettingham and Ilketshall Bt. Margaret are retarned, ${ }^{10}$ all five charches being appropriated to the Benedictine nannery of Bungey. ${ }^{14}$ It is important to note that the schedales of benefices not exceeding ten marks which are appended to some dioceses do not supplement the ordinary returns and were only compiled in 1294, when they were exempt, because in that year Edward I took a moiety instead of a tenth. ${ }^{\prime 2}$ In many dioceses it is not poseible to determine that a benefice has not been appropriated, since the vicarage may not exceed six marks and will not appear in the return, and a calculation of the number of vicarages in 1891 will probably bo too low. Thus there is no echedule of benefices not exceeding eix marks for the diocese of Norvich, and in the county of Norfolk only 723 benefioes were yet 782 are entered in the Norrich taxation, including about 20 ehurches in the city of Norwich which escaped tarstion because the revenues were too small. ${ }^{14}$ Eighty vicarages were aseesed in 1854 , and in 1291 their number had risen to 176,17 yet only 84 axceoded six marks, the remaining 142 being exempt. In the taration there is merely a note stating that the vicarage was indecimabilus, but in the Domesdey Book of Norwich the ments of these are given. ${ }^{12}$ In the archdeaconry of Suffoll trentytwo vicarages exceded six marks in 1291 ; but it cannot be eariouly contended 1 that the number of vicarages was only 22 , for over 60 other churches were eppropriated to religious houses, ${ }^{140}$ and an obvious deduction which might be verified in the Domesday Book of Norwich is that there prere vicarages in these churches below the legal amount. The absence of vicarages, and also of portions, with one exception, in the Norwich taration for the archdeaconry of Buffolk has been commented upon because the majority of the 82 vicarage asesed in 1291 were ordained before $1254,{ }^{1+1}$ but a comperison betreen the relative rise of the essessments for the archdeaconries of Buffolk and Budbury warrents a conjecture that in the return for Buffolk benefico, vicarage, and portion are entered together as one total.

Ross Gratax.

1. P Nick Tar. p. 118.

* Cal of Pat Rolls, 20 Rd. I, m. 8.

wo Moid p. 290.

17 Viet Couraty Hist $S$ ig jolk, if. 14

11' Viet Courity But Swfolk, if. 11, 14. ar Fich Cownty Birth Swfolk, if. 81

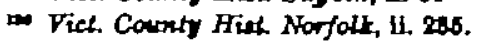

in Ibid.

10 P. Nich Tax. pp. 118-0. 